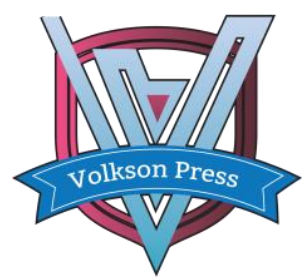

Contents List available at VOLKSON PRESS

Economics \& Management Innovations(EMI)

DOI : http://doi.org/10.26480/icemi.01.2017.365.366

\title{
Research and analysis on foreign trade development level in Heyuan City
}

\section{YE Ying-xia}

HeYuan Polytechnic, HeYuan, Guangdong, China

email: 316889799@qq.com

This is an open access article distributed under the Creative Commons Attribution License, which permits unrestricted use, distribution, and reproduction in any medium, provided the original work is properly cited.

\section{ARTICLE DETAILS}

\section{Article History:}

Received 02 october 2017

Accepted 06 october 2017

Available online 11 october 2017

\section{Keywords:}

Heyuan City; foreign trade development; Research and analysis.

\section{ABSTRACT}

Regional foreign trade development level is closely related to scale merit, structure index and efficiency index of foreign trade development in this region. In this paper, ten years of foreign trade related data in Heyuan city from 2006 to 2015 are used; the writer calculates and analyzes the ratio of dependence on foreign trade, the proportion of foreign capital, foreign trade product structure index, structure index of modes of foreign trade, contribution rate of foreign trade development to GDP, pulling rate of FDI on economic growth, and other important indexes, values and development trends in Heyuan region. The results show that ratio of dependence on foreign trade, the proportion of foreign capital, contribution rate of foreign trade development to GDP, pulling rate of FDI on economic growth is lower, which illustrates that economic development of Heyuan City mainly depends on domestic trade, and international trade development has a enormous space. However, structure index of foreign trade product is higher, which shows that in the types of export products, exports of manufactured goods have a higher proportion, and the structure of export commodities is reasonable.

\section{Introduction}

Heyuan City is located in the northeast of Guangdong province, which is an excellent tourist city in China and mountainous city in northern Guangdong. During the period of "11th Five-Year" and "12th Five-Year", by undertaking industrial transfer, economic structure and industrial structure can be optimized and adjusted in Heyuan City. In 2016, the import and export volume reached twenty-six billion one hundred million Yuan, which increase 4\% over the previous year. (Guangdong decreased slightly by $0.8 \%$ over the same period). Under the increasing of downward pressure of foreign trade development in Guangdong province, it is not easy for Heyuan City still to maintain good growth momentum. But, on the whole, foreign trade development level in Heyuan City is still backward, in this paper, according to the statistical yearbook from 2006 to 2015, and the statistical bulletin on national economic and social development in Heyuan City, the writer queries or calculates the indicators of foreign trade development, and provides references for the further study and analysis of the above indicators.

\section{Analysis on development level of foreign trade in Heyuan}

\subsection{The scale merit of foreign trade development}

The scale merit of foreign trade development reflects the size and change of the amount of trade in a certain period. Which include total exportimport volume (export volume, import volume), ratio of dependence on foreign trade (export dependence, import dependence) and proportion of foreign capital. These three indicators comprehensively reflect the development scale of regional foreign trade, the bigger the volume is, the bigger the development scale of regional foreign trade is, the stronger ability of sustainable development is, and the converse is also true.

Thereinto, the ratio of dependence on foreign trade = regional total import and export volume / region GDP;

Proportion of foreign capital = actual utilization of foreign capital / regional fixed assets investment.

The import and export volume, export volume, import volume, ratio of dependence on foreign trade and the proportion of foreign capital in Heyuan from 2006 to 2015 are shown in table 1and figure 1.

Table 1: The scale merit of foreign trade development in Heyuan from 2006 to 2015

\begin{tabular}{|l|l|l|l|l|l|}
\hline & $\begin{array}{l}\text { Impor } \\
\text { t and } \\
\text { export } \\
\text { volum } \\
\text { e } \\
\text { unit: } \\
\text { millio } \\
\text { n } \\
\text { dndex } \\
\text { dollar } \\
\text { s) }\end{array}$ & $\begin{array}{l}\text { Export } \\
\text { volume(un million } \\
\text { dollars) }\end{array}$ & $\begin{array}{l}\text { Import } \\
\text { volume(un } \\
\text { it: million } \\
\text { dollars) }\end{array}$ & $\begin{array}{l}\text { Ratio of } \\
\text { dependen } \\
\text { ce on } \\
\text { foreign } \\
\text { trade (unit } \\
: \%)\end{array}$ & $\begin{array}{l}\text { Proporti } \\
\text { on of } \\
\text { foreign } \\
\text { capital } \\
\text { (unit :\%) }\end{array}$ \\
\hline 2006 & 9.96 & 5.58 & 4.39 & 29.47 & 10.48 \\
\hline 2007 & 15.57 & 8.95 & 6.62 & 34.62 & 9.26 \\
\hline 2008 & 19.71 & 12.47 & 7.24 & 34.26 & 12.45 \\
\hline 2009 & 22.26 & 14.13 & 8.13 & 36.36 & 7.80 \\
\hline 2010 & 27.16 & 17.15 & 10.01 & 38.07 & 4.61 \\
\hline 2011 & 27.93 & 19.16 & 8.77 & 30.57 & 4.78 \\
\hline 2012 & 29.26 & 19.53 & 9.73 & 29.96 & 4.45 \\
\hline 2013 & 32.32 & 22.47 & 9.85 & 29.41 & 3.81 \\
\hline 2014 & 39.55 & 26.49 & 13.06 & 31.94 & 3.06 \\
\hline 2015 & 40.3 & 28.3 & 12.0 & 31.84 & 1.63 \\
\hline & & & & & \\
\hline
\end{tabular}

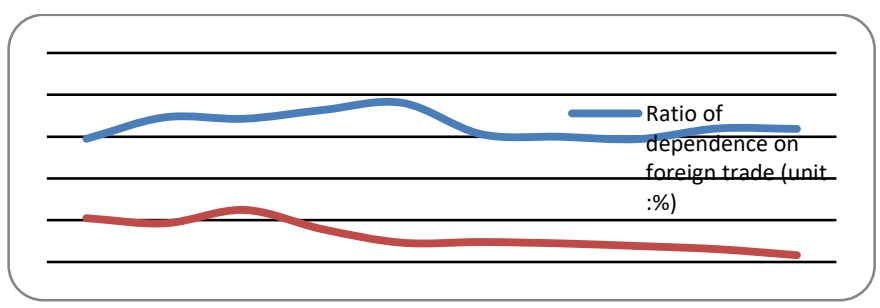

Fig.1: Ratio of dependence on foreign trade and Proportion of foreign capital t in Heyuan City from 2006 to 2015.

From table 1, we know that the ratio of dependence on foreign trade in Heyuan City from 2006 to 2015 kept at about 30\% over a long period of time, which had a bigger difference from that the ratio of dependence on foreign trade in the Pearl River Delta region and Guangdong province has 
remained above $95 \%$ for the year. On one hand, it shows that the dependence of economical and foreign trade development in Heyuan is not strong, and on the other hand, the foreign trade of Heyuan still has a larger space to develop. Besides, the proportion of foreign capital in Heyuan from 2006 to 2015 was much lower, basically under $10 \%$. This shows that in the investment in fixed assets of Heyuan areas, actual utilization of FDI has a relatively low proportion. The government of Heyuan and the related foreign trade enterprises should make efforts to increase the introduction of foreign capital and raise the amount of actually utilized foreign capitals to lead the economic development in Heyuan.

\subsection{The structure and performance indicator of foreign trade development}

The structure indicator of foreign trade development can be divided into commodity structure index of foreign trade, mode structure index of foreign trade, and market structure index of foreign trade.

Thereinto, commodity structure index of foreign trade= export volume of manufactured goods / export volume of primary products;

Mode structure index of foreign trade= the volume of processing trade/ export volume;

The export areas of foreign trade in Heyuan are mainly concentrated in new and high-tech zones and Dongyuan County, and export countries and regions include the United States, Hongkong, the European Union, Japan and so on, and the export to those counties and regions is accounted for more than $80 \%$ of all exports in Heyuan. In recent year, the amount of Heyuan's exports to ASEAN has improved. This is benefited from the establishment of free trade zone in Guangdong Province and the radiation effect of Guangdong Province as a strategic hub of Maritime Silk Road in the 21 century.

The economic efficiency index of foreign trade development reflects the promoting function of foreign trade development on regional economies, which includes the contribution rate of foreign trade development to GDP and pulling rate of FDI to economic growth.

Inside, the contribution rate of foreign trade development to GDP=the net export increments of foreign trade/increments of GDP;

Pulling rate of FDI to economic growth=FDI/ GDP* the growth rate of GDP.

The above indicators are shown in Table 2 and figure 2.

Table 2: The structural indicators of foreign trade development in Heyuan

\begin{tabular}{|l|l|l|l|l|}
\hline & $\begin{array}{l}\text { Commodity } \\
\text { structure } \\
\text { index of } \\
\text { foreign } \\
\text { trade }\end{array}$ & $\begin{array}{l}\text { Mode } \\
\text { structure } \\
\text { index of } \\
\text { foreign } \\
\text { trade (unit } \\
\text { Year }\end{array}$ & $\begin{array}{l}\text { The } \\
\text { contribution } \\
\text { rate of foreign } \\
\text { trade } \\
\text { development } \\
\text { to GDP (unit } \\
: \% \text { ) }\end{array}$ & $\begin{array}{l}\text { Pulling } \\
\text { rate of FDI } \\
\text { to } \\
\text { economic } \\
\text { growth } \\
\text { (unit:\%) }\end{array}$ \\
\hline 2006 & 32.12 & 85.13 & -- & --- \\
\hline 2007 & 31.35 & 88.38 & 36.44 & 1.34 \\
\hline 2008 & 29.02 & 83.88 & 39.02 & 0.87 \\
\hline 2009 & 27.82 & 86.27 & 49.54 & 0.20 \\
\hline 2010 & 25.77 & 87.52 & 34.56 & 0.29 \\
\hline 2011 & 14.08 & 83.29 & 12.24 & 0.35 \\
\hline 2012 & 16.75 & 81.62 & 6.48 & 0.12 \\
\hline 2013 & 19.23 & 75.43 & 27.97 & 0.18 \\
\hline 2014 & 23.30 & 70.71 & 31.34 & 0.19 \\
\hline 2015 & 25.22 & 69.61 & 22.66 & 0.072 \\
\hline
\end{tabular}

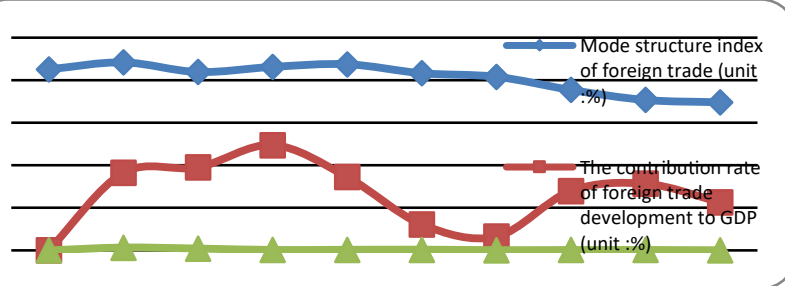

Fig.2: The contrast in the structural indicators of foreign trade development in Heyuan City from 2006 to 2015
From table 2, we know that commodity structure index of foreign trade in Heyuan City have a relatively large volume, which shows that export volume of manufactured goods in Heyuan City is much higher than the export volume of primary products, and the structure of export commodities is reasonable. The commodity structure index of foreign trade has dropped at first, and then it has raised, it shows that in the professional background of that Heyuan undertook the industry, exports of mechanical and electrical products, electronic digital products and other manufactured goods are rising; The mode structure index of foreign trade in Heyuan is higher on the whole, basically between $70 \%$ and $80 \%$. This shows that ratio of processing trade in Heyuan is large, the development of general trade and service trade are insufficient, as well as the added value of export commodities is low, which is extensive and unreasonable. However, the mode structure index of foreign trade in Heyuan always has a downward trend; it shows that in the process of industrial transformation, Heyuan constantly optimized the mode of foreign trade to make the mode be reasonable; the contribution rate of foreign trade development to GDP in Heyuan is not high, it shows that the impetus function of foreign trade development in Heyuan on Heyuan's economy is not enough; pulling rate of FDI to economic growth in Heyuan City is very small, but it is still a positive value, this reflects that the development of foreign trade has brought positive promotion to Heyuan's economic growth, and which once again proves that foreign trade is the engine of economic growth, at the same time, the influence of foreign trade on Heyuan's economy is also positive.

\section{Conclusions}

The import and export volume as well as export volume in Heyuan City has always kept a increasing and good situation, import volume has a little fluctuation; the ratio of dependence on foreign trade is relatively stable, it maintains at around 30\% generally; the proportion of foreign capital in Heyuan is not high, it reached its highest value in 2008 , and then it has appeared a downtrend. However, in recent year, the export number of primary products has increased; the mode of foreign trade in Heyuan is taken processing trade as main mode, and in recent year, general trade and other modes has been increased, the mode of foreign trade has been constantly optimized. This is consistent with the gradual optimization of structure of goods trade in Guangdong Province; there is an obvious trend of transformation from "foreign enterprise + processing trade" to "private enterprise + general trade"; at the same time, the mechanical and electrical products and labor-intensive products are still the mainstream of foreign trade; The contribution rate of FDI to GDP and the pulling rate of FDI to economy in Heyuan City is extremely low, which has a long distance behind Pearl River Delta region and Guangdong Province. The key points for the future are to attract foreign investment, increase FDI and promote the development of Heyuan's economy.

\section{References}

[1] Chen Shichong, Mei Jinyan, etc. Research on Regional Differences of Export Trade in Hubei Province and their Influencing Factors [J] Pioneering with Science \& Technology Monthly, 2011(17):46-48.

[2] Huang Jingbo, The Empirical Analysis on the Foreign Trade Development in Guangdong Province [M]. Guangdong: Zhongshan University Press, 2006.

[3] Li Jian, etc. Theory and Practice of Speeding up Foreign Trade Development [J], International trade, 2012 (6): 27-35.

[4] Chen Wanling, Li Tieli, The Guangdong Foreign Economic and Trade Blue Book: Research Report on the Foreign Economic and Trade Development in Guangdong (2011-2012)[M],Social Science Academic Press,2013.

[5] Guangdong Bureau of Statistics, Guangdong Statistical Yearbook 2012 [M].Guangdong Economic Publishing House,2013.

[6] Yang Youxiao, Chen Wenliang.Study on the relationship between regional development differences and the transformation and upgrading of foreign trade in Guangdong Province [J].International economic and trade exploration,2014 (1): 101-112.

[7] Zhuang Rui,Bai Guangyu, Fang Tie.FDI in China's distribution changes in China's foreign trade transformation and upgrading of the impact[J]. International Trade, 2013 (1): 13-21.

[8] Tu Jing. The Impact of Changes in International Economic Situation on China's Foreign Trade [J]. International Economic Cooperation, 2012 (4): 14-16. 